\title{
TEKNOLOGI INOVATIF PENGOLAHAN MAKANAN UNTUK PENINGKATAN KAPASITAS PRODUKSI UMKM DI KABUPATEN SIDOARJO
}

\author{
Amallia Puspitasari*, Desi Erlita, Ucik Ika Fenti Styana \\ Fakultas Teknologi Industri \\ Institut Teknologi Yogyakarta \\ Jl.Gedong Kuning Km 4 Yogyakarta \\ Email Korspondensi: *amalliapuspitasari@ity.ac.id
}

Received : November 30, 2020 ; Accepted : December 18 , 2020 ; Published : January $1^{\text {st }}, 2021$

\begin{abstract}
Abstrak
Kabupaten Sidoarjo terkenal sebagai salah satu pusat industri makanan olahan, seperti usaha keripik singkong dan kerupuk udang oleh UMKM Berkas Sejahtera. Akan tetapi, permintaan yang tinggi dari konsumen tidak dapat dipenuhi karena keterbatasan produksinya. Melalui kegiatan ini diharapkan mitra UMKM bisa meningkatkan kapasitas produksi dan pendapatan serta menambah lapangan pekerjaan bagi masyarakat di wilayah sekitarnya. Metode dalam kegiatan ini adalah pengembangan teknologi produksi makanan olahan tepat guna. Tahapan yang dilakukan yaitu mengindentifikasi kebutuhan riil mitra terkait operasional produksi, merancang dan membuat mesin produksi makanan olahan tepat guna, pengujian operasional mesin, evaluasi hasil pengujian mesin serta penguatan kelembagaan dan sumber daya manusia. Luaran dari kegiatan ini adalah adanya paket teknologi pengolahan keripik singkong dan kerupuk udang yang terdiri dari mesin perajang singkong, peniris minyak, penggiling daging udang, pengaduk bumbu hexagonal, pencampur adonan, pencetak bentukan kerupuk, pengering kerupuk, serta mesin pengemas (packaging) untuk kerupuk maupun keripik. Hasil yang diperoleh dari kegiatan ini yaitu adanya peningkatan kapasitas produksi mitra UMKM dari produksi 1 ton per hari menjadi 3 ton per hari. Dengan adanya peningkatan kapasitas produksi maka pendapatan juga meningkat dan menambah lapangan pekerjaan bagi masyarakat di wilayah sekitarnya.
\end{abstract}

Kata Kunci: keripik singkong, kerupuk udang, Sidoarjo, teknologi tepat guna

\begin{abstract}
Sidoarjo district is known as one of industrial center processed foods as chips cassava and shrimp crackers by UMKM Berkas Sejahtera. The high demand from the customers can not be covered because of the limitation of technology in production. Through this program is expected to partner businesses can increase the company production capacity, income and job opportunities for the community. Method used in this program is developing of efficient processed food production technology. Activities stages in this program were to identify real needs related production partner operational, designed and manufactured the production of processed foods effective, operational testing machine, evaluation machine, and intitutional strengthening and human resources. The output of this program are the package processing technology chips cassava and prawn crackers consist of cassava chopper, spinner, meat grinder, the hexagonal stirer seasoning, mixer the batter, press crackers,drying machine crackers and packaging machine. The results of the program is improving partner production capacity such that the program can be increasing from 1tons
\end{abstract}


per day into 3 tons per day. So can increase income and job opportunities for the people in surrounding region.

Keywords : chips cassava, shrimp crackers, Sidoarjo, efficient technology

\section{Pendahuluan}

Usaha Mikro Kecil dan Menengah memegang peranan sangat penting dalam menunjang perekonomian negara. Kehadiran UMKM bukan saja untuk peningkatan pendapatan tapi juga dalam rangka pemerataan pendapatan. Hal ini bisa dimengerti karena sektor UMKM melibatkan banyak orang dengan beragam usaha. Pemerintah sudah mempunyai komitmen memberdayakan ekonomi kerakyatan dalam hal ini UMKM dan koperasi. Namun misi ini sempat belum terlaksana dengan baik, seiring dengan sikap pemerintah yang masih mengandalkan usaha besar sebagai motor pertumbuhan ekonomi. Peranan UMKM yang fleksibilitas mampu menyerap tenaga kerja dengan cepat tanpa memandang tinggi rendahnya pendidikan para tenaga kerjanya, sehingga UMKM selain berperan penting dalam ekonomi nasional juga berperan menanggulangi tingkat pengangguran [1].

UMKM menghadapi berbagai kendala dalam pengembangan usahanya. Beberapa kendala yang dihadapi UMKM di antaranya adalah: permodalan, pemasaran, bahan baku, teknologi, manajemen, birokrasi, infrastruktur, dan kemitraan. Oleh karena itu, keberadaan UMKM perlu diperhatikan agar dapat menjadi wadah bekerja yang baik dan mampu bersaing dengan perkembangan jaman yang pesat serta dapat meningkatkan kualitas masyarakat menjadi lebih baik sehingga memberikan dampak baik pada perekonomiaan nasional [2].

Salah satu jenis UMKM yang sangat diandalkan dalam menunjang perekonomian daerah adalah usaha produksi makanan olahan. Usaha ini mampu bertahan dalam kondisi krisis ekonomi karena kebutuhan akan makanan akan terus ada sampai hari akhir nanti. Selain itu, pola konsumsi masyarakat yang lebih modern mendorong mereka untuk mengkonsumsi makanan olahan. Hal ini mempercepat perkembangan UMKM ini, sehingga bisa membuka lapangan pekerjaan yang cukup besar bagi warga masyarakat.

Salah satu usaha produksi makanan olahan yang berkembang di Kabupaten Sidoarjo adalah usaha keripik singkong dan kerupuk udang "Berkah Sejahtera" yang ada di Desa Rejeni, Kecamatan Krembung. Usaha yang dirintis oleh Pak Anang Abidin sejak setahun yang lalu ini, memproduksi keripik singkong dan kerupuk udang skala rumah tangga menggunakan peralatan yang sederhana. Produk-produk yang dihasilkan sudah dipasarkan di daerah sekitarnya di Kecamatan Krembung. Bahkan, beberapa kali juga sudah dipasarkan ke daerah lain di wilayah Sidoarjo dan sekitarnya. Hal ini disebabkan karena cita rasa dari produk keripik dan kerupuk udang yang diproduksi cukup enak dan pas di lidah konsumen. Produk andalan dari kerupuk yang diproduksi, ditunjukkan dalam Gambar 1.
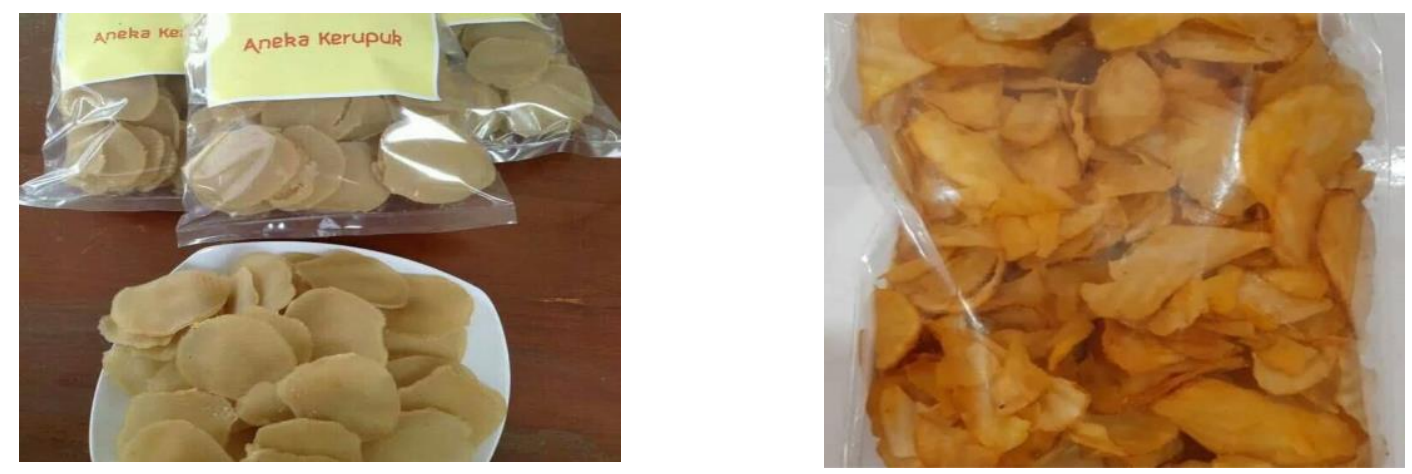

Gambar 1. Kerupuk Udang dan Keripik Singkong Berkah Sejahtera 
Dalam menjalankan usaha kerupuk, Berkah Sejahtera mendapatkan bahan baku dari sekitar wilayah Kabupaten Sidoarjo, yang merupakan sentra perikanan udang di Jawa Timur. Sementara untuk bahan baku keripik singkong didapatkan suplai dari beberapa daerah sentra ubi singkong di Jawa Timur. Kapasitas produksi Berkah Sejahtera masih kecil, yaitu 1 ton per hari. Hal ini disebabkan proses produksi keripik singkong dan kerupuk udang tersebut masih dilakukan oleh keluarga tanpa melibatkan tenaga kerja dari luar. Jumlah tenaga kerja hanya berjumlah 5 orang dan ketrampilan terbatas. Selain itu, peralatan yang digunakan masih manual dan sederhana sehingga sangat sulit untuk mengembangkan usahanya. Sebagai contoh, mereka masih menggunakan pisau untuk mengiris singkong secara manual serta menggunakan mengeringkan adonan kerupuk udang dengan cara menjemur di bawah terik matahari. Proses pengeringan dengan penjemuran tersebut sering terhambat dengan cuaca yang tidak menentu sehingga terkadang memubutuhkan waktu yang lama untuk pengeringan. Proses produksi dan pengeringan terlihat seperti dalam Gambar 2.
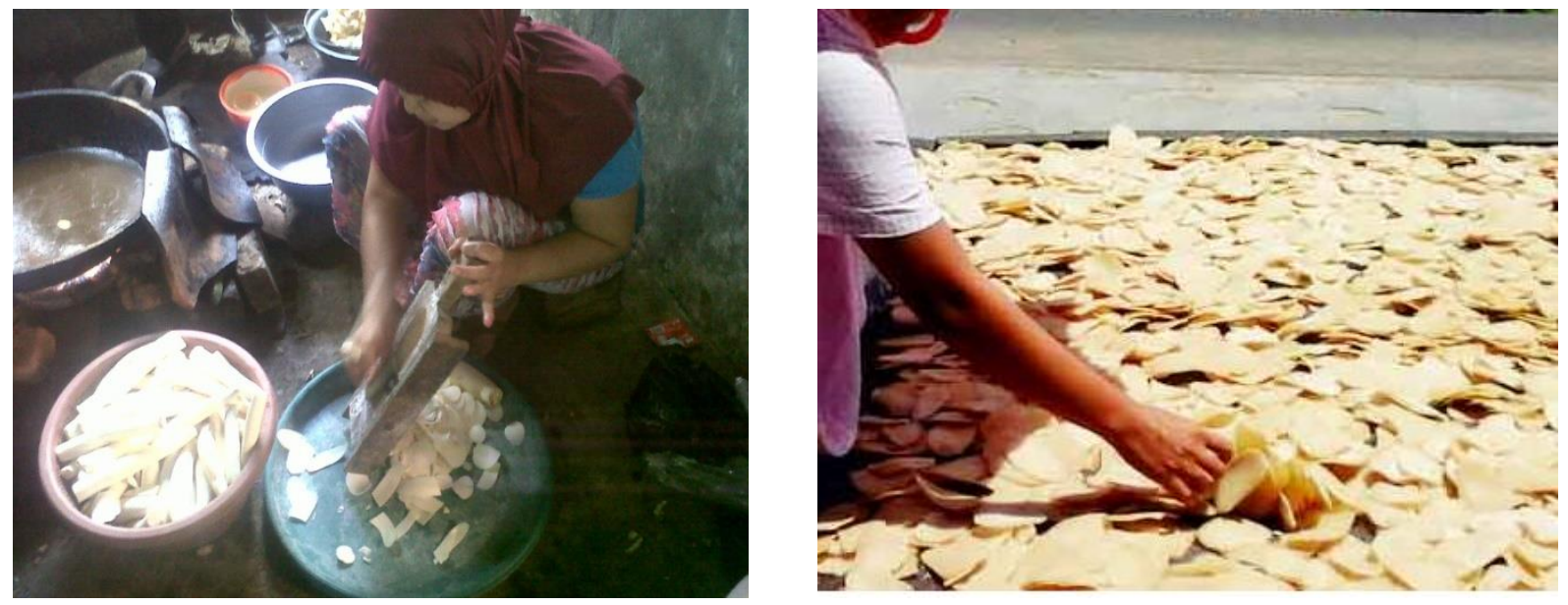

Gambar 2. Produksi Kerupuk Udang dan Keripik Singkong Sederhana

Dengan peralatan yang masih sederhana dan manual serta tenaga kerja yang terbatas, Berkah Sejahtera seringkali tidak dapat memenuhi tingginya permintaan konsumen. Dalam satu bulan permintaan konsumen yang tidak dapat dipenuhi bisa mencapai 7 ton.

Selain peralatan yang masih sederhana, pemasaran usaha kerupuk udang dan keripik singkong Berkah Sejahtera masih dilakukan secara konvensional dari pintu ke pintu. Ada kelompok pemuda Krembung Jaya yang membantu secara online namun masih terbatas. Kumpulan anak-anak muda di wilayah Krembung tersebut juga membantu Berkah Sejahtera untuk mendistribusikan ke toko dan warung yang ada di sekitar tempat tinggal mereka.

Melalui kegiatan ini diharapkan bisa dirumuskan sebuah sistem pengembangan UMKM makanan olahan melalui penerapan teknologi mesin pengolahan makanan tepat guna di masyarakat/pelaku usaha, hingga terjadi peningkatan kapasitas produksi yang secara otomatis akan meningkatkan pendapatan masyarakat. Melalui kolaborasi yang tepat antara perguruan tinggi, pemerintah daerah, dan industri, diharapkan penerapan teknologi produksi makanan olahan ini mampu dimanfaatkan menjadi produk yang bernilai dengan mutu terjamin dan bisa menghasilkan tambahan pendapatan bagi mitra dan masyarakat pada umumnya. UMKM membutuhkan peralatan-peralatan inovatif yang bisa membantu kinerja mereka sehingga bisa meningkatkan produksinya sampai berkali-kali lipat. Hal ini diperlukan agar mereka mampu memenuhi permintaan konsumen. 
Peluang pasar makanan olahan seperti keripik singkong dan kerupuk udang yang begitu besar di Kabupaten Sidoarjo dan sekitarnya, belum diimbangi dengan kemampuan pelaku usaha yang merupakan usaha berskala UMKM, seperti usaha keripik singkong dan kerupuk udang Berkah Sejahtera. Awalnya, peralatan yang digunakan untuk proses produksi berupa peralatan dapur yang sederhana, seperti pisau, kompor, panci, wajan, dan peralatan lainnya. Akan tetapi, kapasitas mereka masih sangat kecil, sehingga mereka membutuhkan peralatan dengan kapasitas yang lebih besar untuk memperbesar skala usahanya.

Beberapa peralatan utama yang dibutuhkan oleh Berkah Sejahtera adalah alat untuk mengiris singkong, alat untuk meniriskan minyak hasil penggorengan agar tidak mudah tengik, serta alat untuk mencampur bumbu tabur pada keripik singkong agar memiliki bermacam rasa. Sementara untuk produksi kerupuk udang, mereka membutuhkan peralatan untuk menggiling daging sendiri yangs selama ini mereka gilingkan di pasar. Termasuk juga alat untuk mencampur adonan kerupuk, dan alat untuk memotong adonan kerupuk berbentuk lontongan menjadi tipis-tipis agar mudah untuk digoreng. Peralatan lainnya yang tidak kalah penting adalah mesin untuk pengemasan produknya, dimana mereka masih menggunakan tali ikatan maupun lilin untuk merekatkan plastik pembungkus keripik dan kerupuk tersebut, sehingga kinerjanya sangat lambat dan kurang efisien.

Selain dari sisi produksi, hal lain yang tidak kalah penting adalah perlunya penguatan kelembagaan (capacity building) berupa pendampingan dari sisi manajemen keuangan, pemasaran, sampai pengelolaan sumber daya manusia apabila usaha UMKM tersebut berkembang besar nanti. Hal ini mutlak diperlukan agar perusahaan tersebut bisa bertahan di tengah persaingan dengan usaha lain, bahkan bisa menjadi leading company dalam penyediaan makanan olahan higienis dan berharga terjangkau.

Secara umum capacity building adalah proses atau kegiatan memperbaiki kemampuan seseorang, kelompok, organisasi atau sistem untuk mencapai tujuan atau kinerja yang lebih baik. Capacity building adalah pembangunan keterampilan (skills) dan kemampuan (capabilities), seperti kepemimpinan, manajemen, keuangan dan pencarian dana, program dan evaluasi, supaya pembangunan organisasi efektif dan berkelanjutan. Ini adalah proses membantu individu atau kelompok untuk mengidentifikasi dan menemukan permasalahan dan menambah wawasan, pengetahuan dan pengalaman yang dibutuhkan untuk memecahkan masalah dan melakukan perubahan [3]. Capacity building merupakan suaatu upaya yang berhubungan dengan peningkatan kualitas sumber daya manusia, upaya untuk mendorong organisasi agar dapat berjalan sesuai dengan fungsinya, serta upaya untuk menciptakan kondisi lingkungan yang dibutuhkan oleh organisasi agar dapat berfungsi dengan baik [4].

Sisi manajemen juga perlu diperhatikan dalam mengembangkan usaha. Salah satu kunci keberhasilan dalam mengembangkan usaha adalah pada manajemen pengelolaan usaha. Banyak usaha yang bangkrut karena pengelolaan usaha nya yang kurang bagus. Tak peduli berapa banyak modal usaha yang dimiliki lama kelamaan akan habis juga jika tidak bisa mengelola dengan baik [5].

Khusus untuk pemasaran, adanya Kelompok Pemuda Krembung Jaya cukup membantu pemasaran produk kerupuk tersebut, khususnya secara online di media sosial. Akan tetapi, sistem marketing online tersebut perlu diperluas lagi dengan membuat website maupun e-commerce khusus yang didukung oleh sarana pendukung seperti wifi dan webhousting. Hal ini diperlukan agar penetrasi pasar mereka lebih cepat dan produknya bisa lebih dikenal oleh masyarakat luas.

Oleh karena itu melalui kegiatan ini, diharapkan bisa membantu meningkatkan kewirausahaan pelaku usaha produksi makanan olahan di Kabupaten Sidoarjo ini untuk meningkatkan kinerja dalam pengembangan usaha berskala UMKM, baik dari sisi produksi, pemasaran, manajemen keuangan, sampai pengelolaan sumber daya manusia. 


\section{Metode}

Metode pelaksanaan program yang diterapkan adalah pengembangan teknologi pengolahan makanan olahan tepat guna untuk usaha kecil dan menengah (UMKM) yang meliputi:

1. Identifikasi kebutuhan UMKM. Identifikasi kebutuhan mitra yang disesuaikan dengan rencana kapasitas produksi UMKM. Hal ini berkaitan dengan pendalaman data mengenai:

- Profil UMKM Mitra secara keorganisasian, untuk memetakan permasalahan Mitra dalam peningkatan kapasitas produksi dan jangkaun pemasaran mitra.

- Kapasitas produksi UMKM Mitra. Untuk dapat melihat sejauh mana pengembangan dan peningkatan kapasitas produksi hasil yang akan disesuaikan dengan jangkauan pemasaran mitra UMKM.

- Jangkauan Pemasaran Mitra. Dengan mengetahui jangkauan pasar UMKM dapat disinkronkan dengan rencana kapasitas maksimum hasil yang dapat kembangkan pada mesin olahan tersebut.

2. Perancangan dan Pembuatan Mesin.

Setelah mendapatkan detail informasi mengenai profil mitra maka dilanjutkan pada modifikasi teknologi yaitu pengembangan mesin pengolahan yang dimulai dari desain perancangan kapasitas produksi dan pembuatan mesin.

- Mendesain pengembangan mesin produksi makanan olahan tepat guna. Melakukan re-desain terhadap teknologi yang telah ada melalui peningkatan kapasitas produksi mesin produksi makanan olahan tepat guna.

- Membuat mesin produksi makanan olahan tepat guna berdasarkan dengan desain.

3. Pengujian Operasional Mesin.

Setelah pembuatan mesin selesai dilakukan maka dilanjutkan dengan tahapan berikutnya yaitu melakukan pengujian terhadap operasional mesin tersebut. Tahapan pengujian ini dilakukan untuk melihat kehandalan dari mesin yang telah dibuat. Adapun langkah-langkah yang dilakukan adalah sebagai berikut:

- Melakukan pengujian operasional mesin di bengkel

- Melakukan pengujian operasional mesin di masyarakat

- Melakukan evaluasi terhadap hasil uji mesin di masyarakat

4. Serah Terima Alat

Serah terima peralatan dilakukan setelah peralatan berhasil diuji coba dengan baik dan dikirimkan ke lokasi mitra penerima peralatan tersebut. Peralatan diserah terimakan oleh tim pelaksana kepada mitra disaksikan oleh stakeholder yang terkait.

5. Penguatan Kelembagaan (Capacity Building) dan Sumber Daya Manusia

- Proses pendampingan penerapan mesin produksi makanan olahan tepat guna berskala UMKM dengan melibatkan semua pihak yang terkait.

- Pelatihan proses produksi makanan olahan tepat guna untuk peningkatan kompetensi sumber daya manusia mitra UMKM dengan berbasis teknologi mesin produksi makanan olahan yang sudah didiseminasikan. Melalui pelatihan ini, diharapkan mereka memahami apa yang harus dilakukan di lapangan dalam mengimplementasikan program ini.

- Pendampingan pada aspek manajemen keuangan, pembukuan, pemasaran, sampai manajemen pengelolaan SDM yang bekerja

- Pendampingan ini akan diberikan secara terus-menerus sampai terjadi peningkatan kapasitas produksi dan omzet usaha serta penambahan jumlah tenaga kerja yang bisa bekerja dengan baik. 


\section{Hasil dan Pembahasan}

Hasil dari program ini adalah Pengembangan teknologi pengolahan makanan olahan tepat guna untuk usaha kecil dan menengah (UMKM), serah terima alat, serta Penguatan Kelembagaan (Capacity Building) dan Sumber Daya Manusia. Hasil dari kegiatan ini dapat diuraikan sebagai berikut:

\subsection{Pengembangan teknologi pengolahan makanan olahan tepat guna untuk usaha kecil dan menengah (UMKM)}

Proses pembuatan teknologi pengolahan makanan olahan tepat guna berupa peralatan dilakukan di bengkel rekayasa selama 4 minggu. Paket teknologi berupa peralatan terdiri dari mesin perajang singkong, pengaduk bumbu hexagonal, peniris minyak, penggiling daging/ udang, pencampur adonan, pencetak bentukan kerupuk, pengering kerupuk, serta mesin pengemas (packaging) untuk kerupuk maupun keripik. Beberapa peralatan ditunjukkan dalam Gambar 3.

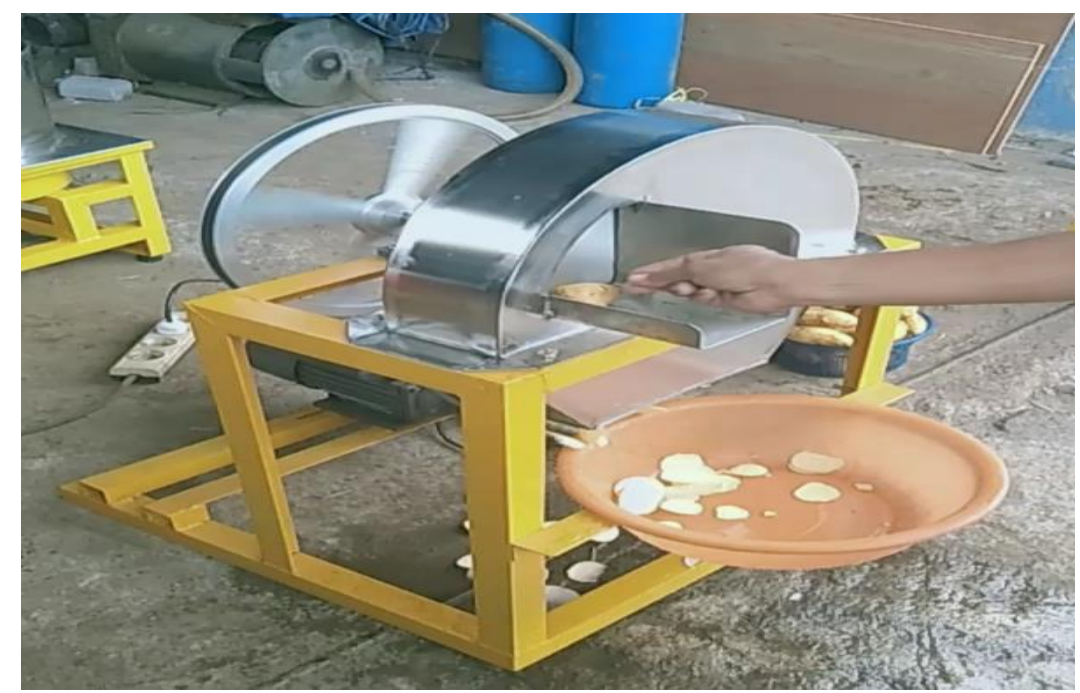

Gambar 3. Mesin perajang Singkong

Mesin perajang singkong dilengkapi dengan motor penggerak yang di teruskan pada pemotong utama pisau pengiris yang bergerak vertikal satu arah. Dengan menggunakan sistem gerak ini tenaga yang dihasilkan cukup besar sehingga dapat memotong bahan [6]. Selama ini proses pemotongan singkong di UMKM Berkah Sejahtera dilakukan dengan manual menggunakan pisau tangan sehingga produksinya pun menjadi terbatas. Selain itu pemotongan/ perajangan yang dilakukan secara manual menghasilkan potongan singkong yang tidak seragam, baik besar kecilnya maupun tebal tipisnya. Padahal ketebalan irisan mempengaruhi kerenyahan keripik. Dengan adanya mesin peranjang singkong maka produksinya bisa meningkat. Kapasitas dari mesin perajang singkong ini adalah $80 \mathrm{~kg} / \mathrm{jam}$. Mesin perajang singkong inipun dapat memotong dengan hasil irisan yang seragam dan tentunya lebih higienis. 


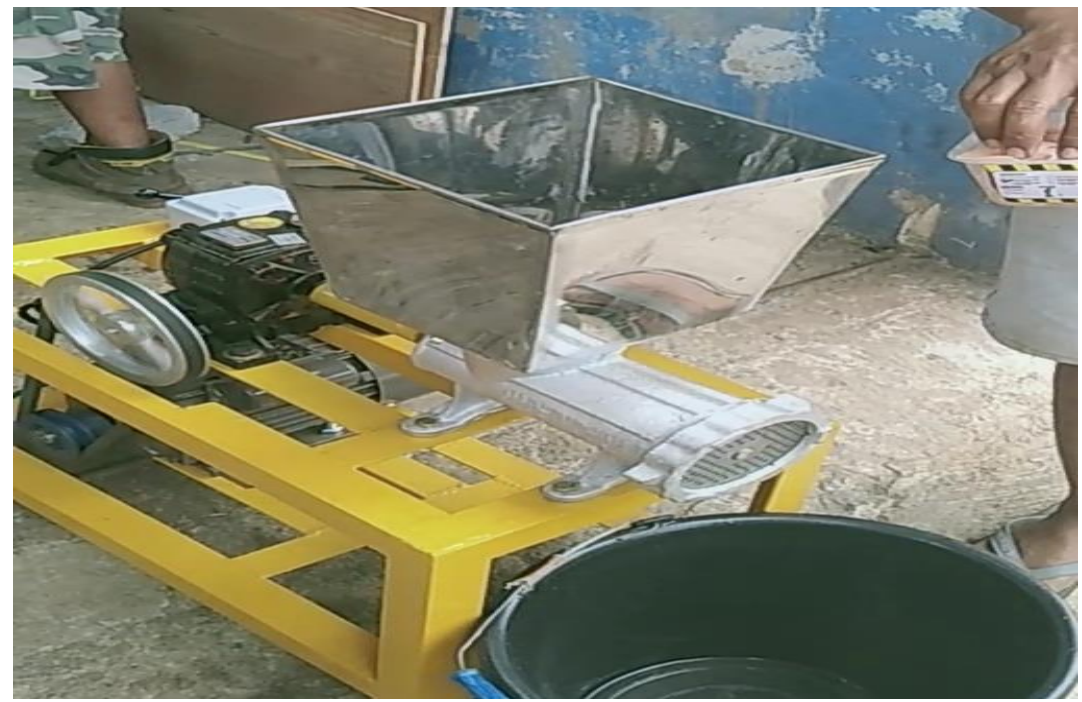

Gambar 4. Mesin Penggiling Daging/Udang

Mesin penggiling daging adalah suatu mesin yang berfungsi untuk menghaluskan dan melembutkan daging yang akan digunakan sebagai bahan makanan atau campuran makanan. Daging yang belum digiling biasanya masih dalam bentuk potongan-potongan kecil yang tidak dapat dicampur dengan bahan lain dalam suatu adonan makanan, sehingga dibutuhkan proses penghaluskan lebih dahulu untuk memudahkan pencampuran daging dengan bahan makanan yang lain. Proses penggilingan daging termasuk dalam proses utama [7].

Mesin Penggiling yang dibutuhkan UMKM Berkah Sejahtera ini adalah mesin untuk menggiling daging udang sebagai bahan baku kerupuk. Mesin ini terbuat dari bahan stainless steel, daya listrik yang rendah dan juga pengoperasian mesin yang sangat mudah. Mesin penggiling bekerja dengan cara menggiling setiap daging udang yang dimasukkan ke corong penggilinggan. Daging yang dimasukkan ke dalam corong penggilingan akan digiling menggunakan pisau Penggiling Daging yang berputar sangat cepat.. Setelah itu daging akan keluar melalui saringan atau sering disebut cetakan, dan hasilnya berupa daging giling.

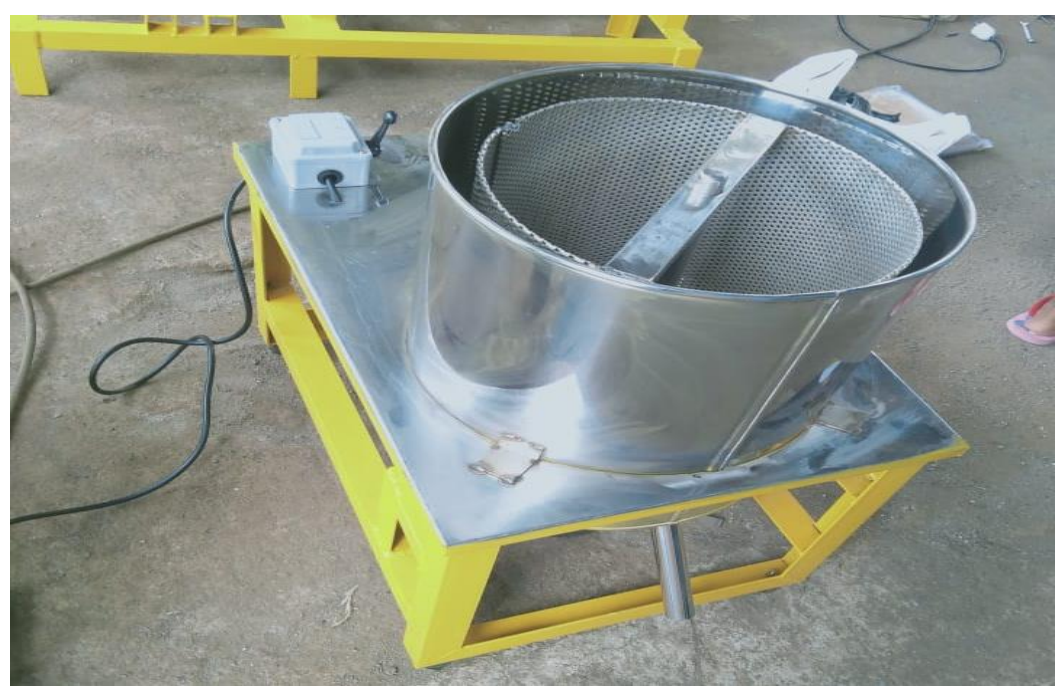

Gambar 5. Mesin Spinner

Mesin spinner atau peniris minyak dengan sistem putar mampu mengurangi kadar minyak dalam makanan dengan cepat. Selain itu keripik jadi lebih awet atau tahan lama, 
keripik yang melalui proses mesin ini juga jauh lebih sehat daripada yang tidak. Mesin spinner bekerja dengan prinsip sentrifugal, bahan makanan seperti keripik atau produk lain yang sedang ditiriskan akan bergerak ke sisi keranjang untuk meniriskan minyak saat keranjang diputar.

Rangka pada mesin peniris minyak berfungsi untuk menopang atau menahan bagianbagian mesin yang ada diatasnya [8]. Oleh karena itu rangka mesin peniris minyak ini dibuat segiempat sehingga dapat menopang stabil. Mesin peniris yang dijual dipasaran hanya rangkanya hanya berbentuk kaki-kaki saja, sehingga pada saat mesin dinyalakan untuk mengeringkan suatu bahan maka gerakannya tidak stabil, mesin tetap berada pada tempatnya.

Selain itu, paket teknologi yang lain adalah peralatan berupa pengaduk bumbu hexagonal, pencampur adonan, pencetak bentukan kerupuk, pengering kerupuk, serta mesin pengemas (packaging) untuk kerupuk maupun keripik. Adanya mesin pengemas (packaging) maka keripik singkong dan kerupuk udang dapat dikemas dengan baik sehingga dapat mempermudah penanganan serta distribusi dan memperpanjang masa simpan produk. Pengemas akan menjaga produk dari perubahan aroma, warna, tekstur yang dipengaruhi oleh perpindahan uap air dan oksigen [9]. Paket teknologi pengolahan makanan olahan tepat guna ini, Berkah Sejahtera dapat meningkatkan kapasitas produksi dari 1 ton per hari menjadi 3 ton per hari. Dengan demikian, permasalahan yang selama ini terjadi yaitu permintaan tinggi dari konsumen tidak dapat dipenuhi karena keterbatasan produksinya saat ini sudah bisa diatasi oleh Berkah Sejahtera.

Tahap selanjutnya dari kegiatan ini adalah pengujian alat. Pengujian alat dilakukan untuk mengetahui apakah mengalami kendala ataukah sudah bisa digunakan. Pada saat pengujian awal terjadi permasalahan pada mesin perajang singkong. Wadah/ tempat penampung irisan singkong tidak dapat menampung semua irisan, jadi banyak irisan yang tercecer. Namun setelah dievaluasi, ternyata terdapat kesalahan pemasangan wadah. Setelah itu dilakukan penyempurnaan dalam hal pemasangan wadah, sehingga mesin perajang singkong dapat beroperasi dengan baik dan hasil irisan dapat tertampung semua di dalam wadah.

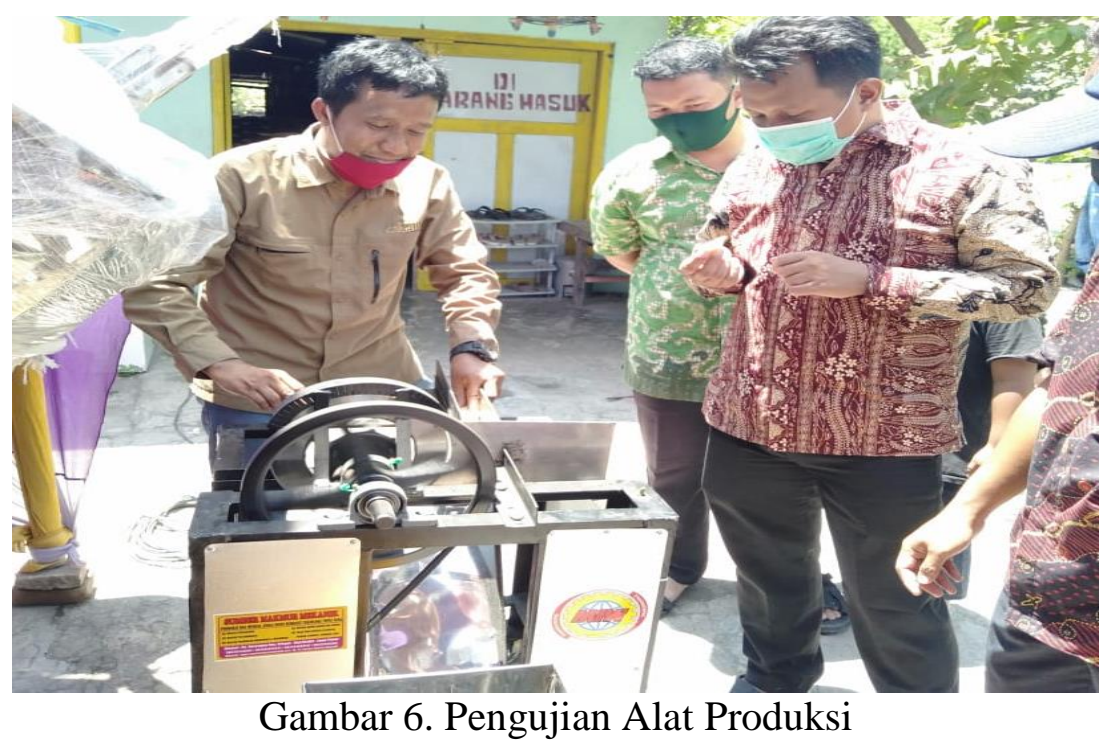

\subsection{Serah Terima Alat}

Serah terima alat dihadiri oleh kedua mitra, beberapa perwakilan anggota UMKM, DPR RI Komisi 7, stakeholder desa setempat, dan perwakilan masyarakat setempat disekitar lokasi dengan tetap menerapkan protokol kesehatan. UMKM dan masyarakat sangat antusias sekali dengan adanya paket teknologi berupa peralatan produksi ini. 


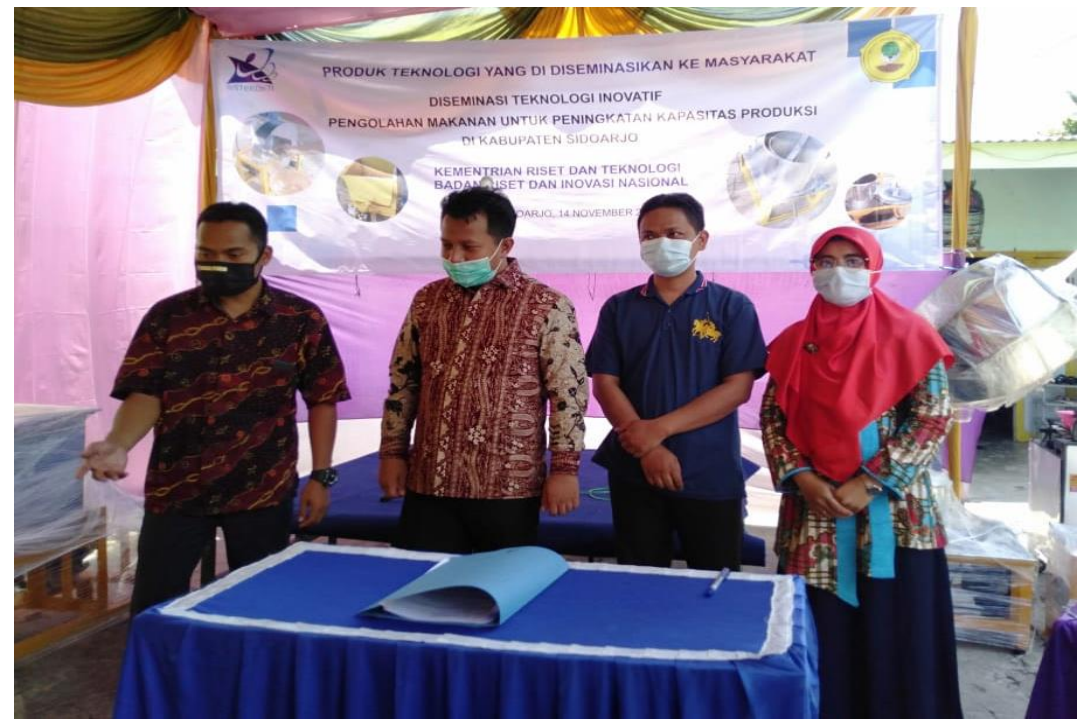

Gambar 7. Kegiatan Serah Terima Alat

\subsection{Penguatan Kelembagaan (Capacity Buliding) dan Sumber Daya Manusia (SDM)}

Penguatan kelembagaan dilakukan melalui proses pendampingan untuk penerapan mesin produksi, pelatihan proses produksi makanan olahan, sistem manajemen baik manajemen keuangan, pembukuan, pemasaran sampai manajemen pengelolaan sumber daya manusia. Pendampingan ini dilakukan terus menerus sampai terjadi peningkatan kapasitas produksi dan penambahan jumlah tenaga kerja. Keterbatasan SDM pada UMKM ini dari segi pendidikan formal maupun pengetahuan dan keterampilannya sangat berpengaruh terhadap manajemen pengelolaan usahanya, sehingga usaha tersebut sulit untuk berkembang dengan optimal. Disamping itu, minimnya pengetahuan mengenai teknologi akan menyulitkan mereka dalam meningkatkan daya saing produk yang dihasilkan [10].

Selain itu, pemasaran merupakan faktor penting dalam pengelolaan usaha. Karena strategi pemasaran merupakan salah satu cara memenangkan keunggulan bersaingan yang berkesinambungan untuk usaha yang memproduksi barang atau jasa. Kegiatan pemasaran dilaksanakan dari pintu ke pintu dan online yang masih terbatas dibantu oleh Kelompok Pemuda Krembung Jaya. Maka melalu kegiatan ini, sudah tersedia website yang dapat diakses oleh masyarakat luas.. Oleh karena itu, pada kegiatan ini juga dilakukan pelatihan pemasaran berbasis teknologi, dimana UMKM diharapkan mampu memanfaatkan perkembangan teknologi informasi yang sudah berkembang dengan pesat untuk membantu pemasaran produk. Webstite UMKM Berkah Sejahtera yang sudah dibuat ditampilkan pada Gambar 8. 


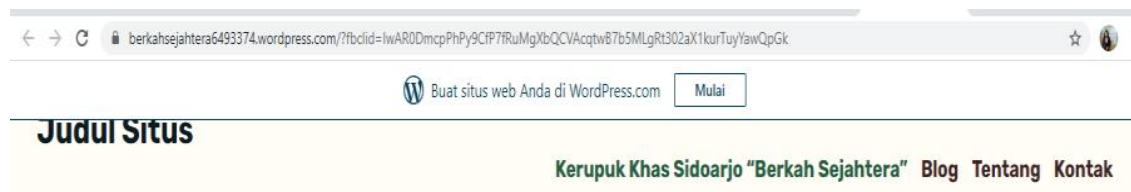

\section{Kerupuk Khas Sidoarjo "Berkah Sejahtera"}

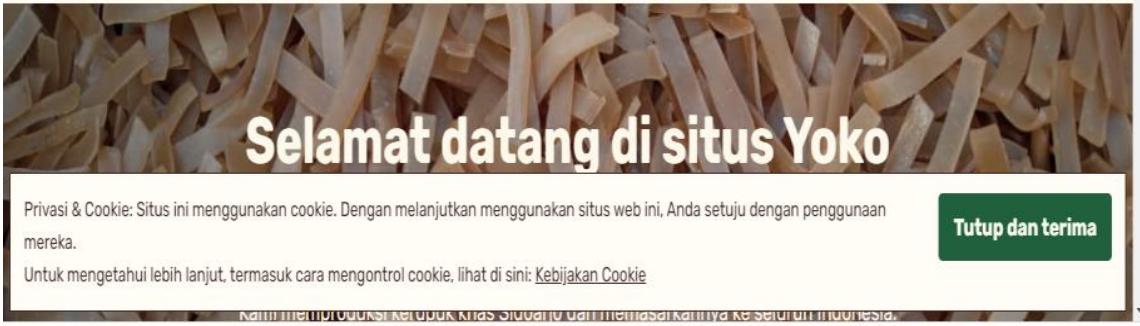

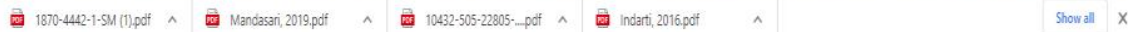

Gambar 8. Website Berkah Sejahtera

Pelaksanaan kegiatan pendampingan produksi dan manajemen juga dilakukan untuk Berkah Sejahtera ditampilkan pada Gambar 9.



Gambar 9. Pendampingan produksi dan Manajemen

\section{Kesimpulan}

Berdasarkan kegiatan yang telah dilakukan, maka dapat disimpulkan bahwa Berkah Sejahtera sudah dapat mengatasi permintaan konsumen yang tinggi dengan adanya paket teknologi makanan olahan tepat guna ini. Paket teknologi pengolahan makanan olahan untuk keripik singkong dan kerupuk udang ada 8 mesin yang terdiri dari mesin perajang singkong, pengaduk bumbu hexagonal, peniris minyak, penggiling daging udang, pencampur adonan, pencetak bentukan kerupuk, pengering kerupuk, serta mesin pengemas (packaging). Dengan adanya paket teknologi berupa peralatan tersebut dapat meningkatkan kapasitas produksi Berkah Sejahtera dari 1 ton per hari menjadi 3 ton per hari. Selain itu, dengan adanya website dan pelatihan pemasaran berbasis teknologi dapat memperluas jangkauan distribusi produk. 


\section{Daftar Pustaka}

[1] Jayanti Mandasari, D., Widodo, J., \& Djaja, S. (2019). Strategi Pemasaran Usaha Mikro, Kecil Dan Menengah (Umkm) Batik Magenda Tamanan Kabupaten Bondowoso. JURNAL PENDIDIKAN EKONOMI: Jurnal Ilmiah Ilmu Pendidikan, Ilmu Ekonomi Dan Ilmu Sosial, 13(1), 123. https://doi.org/10.19184/jpe.v13i1.10432

[2] Padyanawati, A. D., \& Hardjomidjojo, H. (2019). Strategi Peningkatan Daya Saing Usaha Mikro, Kecil, Dan Menengah Di Desa Tegalwaru, Kabupaten Bogor. Jurnal $\begin{array}{lllll}\text { Rekayasa Dan } & \text { Manajemen }\end{array}$ https://doi.org/10.24843/jrma.2019.v07.i01.p15

[3] Industri, P., Di, M., \& Pasuruan, K. (2016). ISBN : 978-602-17225-5-8 ISBN : 978-60217225-5-8.

[4] Anisa, D., Awaliyah, N. F., Cahyanti, S. D., \& Sudrajat, A. R. (2019). Capacity building dalam meningkatkan kualitas sumber daya manusia di Kecamatan Cisarua Kabupaten Sumedang. Konferensi Nasional Ilmu Administrasi, 2, 1-5.

[5] Dewi Sartika Nasution. (2018). Peningkatan Kapasitas Manajemen Usaha Bagi Pelaku Usaha Sektor Industri UKM Roti Sebagai Upaya Peningkatan Daya Saing Usaha Menuju Industri Mandiri. TRANSFORMASI: Jurnal Pengabdian Masyarakat, 14(1), 27-34.

[6] Husman, H., \& Ariyono, S. (2019). Rancang Bangun Mesin Pengiris Singkong. Manutech: Jurnal Teknologi Manufaktur, 10(02), 31-34. https://doi.org/10.33504/manutech.v10i02.65

[7] Porawati, H., \& Kurniawan, A. (2020). Modifikasi mesin penggiling daging (meat grinder) kapasitas $8 \mathrm{~kg}$ menggunakan motor listrik. Jurnal Inovator, 3(1), 20-24. https://doi.org/10.37338/ji.v3i1.110

[8] Sugandi, W., Kramadibrata, A. M., Fetriyuna, \& Prabowo, Y. (2018). Analisis Teknik Dan Uji Kinerja Mesin Peniris Minyak (Spinner). Jurnal Ilmiah Rekayasa Pertanian Dan Biosistem, 6(1), 17-26.

[9] Prasetyawan, Y., Singgih, M. L., Putrianingsih, E., Andriani, Y., \& Ziyad, M. (2014). Peningkatan Produktivitas Usaha Kecil Menengah Kerupuk Udang Melalui Perancangan Pengeringan Dan Pengemasan. Jurnal Metris, 15, 7-14.

[10] Naditya, R., Suryono, A., \& Rozikin, M. (2013). Pengembangan Usaha Mikro, Kecil, Dan Menengah (Umkm) Melalui Fasilitasi Pihak Eksternal Dan Potensi Internal. Universitas Brawijaya, Malang, 1(6), 1086-1095. 
Amallia Puspitasari, Desi Erlita, Ucik Ika Fenti Styana 